\title{
Evaluasi Program Optimasi Lahan Petani Ditinjau Dari Aspek Sosial Ekonomi Petani di Desa Batetangnga Polewali Mandar
}

\author{
Zulkifli Basri \\ Program Studi Agribisnis, Universitas Al Asyariah Mandar \\ Zulkiflibasri02@gmail.com
}

\begin{abstract}
Abstrak
Penelitian ini bertujuan menjelaskan pelaksanaan program pemberdayaan petani melalui kegiatan optimasi lahan, mengevaluasi program pemberdayaan petani melalui kegiatan optimasi lahan, mengetahui dan menganalisis dampak sosial ekonomi pelaksanaan program pemberdayaan petani melalui kegiatan optimasi lahan. Penelitian ini dilaksanakan di Kabupaten Polman Desa Batetangnga Kecamatan Binuang, Kabupaten Polman. Populasi penelitian yaitu 25 kelompok, yang terdiri dari 1 kelompok tani peserta program dan 24 kelompok yang tidak mengikuti program, Sampel kelompok tani peserta ditentukan secara sensus sedangkan sampel kelompok tani bukan peserta program optimasi lahan di tentukan secara porposive. Analisis data yang digunakan secara deskriptif untuk menjelaskan data penelitian dan deskripsi penelitian, sedangkan menganalisis data kuantitatif menggunakan analisis analisis R/C ratio. Hasil penelitian menunjukkan bahwa pelaksanaan program pemberdayaan petani melalui Program Optimasi Lahan sesuai dengan Standar Operasional yang telah ditetapkan, yaitu persiapan, pelaksanaan fisik, pengawalan dan pendampingan. Realisasi kegiatan program optimasi telah memenuhi target yaitu 500.000 hektar. Dampak sosial dilihat berdasarkan kerjasama petani dalam kelompok tani yang diarahkan untuk penerapan sistem agribisnis, peningkatan peranan, peran serta petani dan anggota masyarakat, menggali potensi, memecahkan masalah usaha tani anggotanya secara lebih efektif dan memudahkan dalam mengakses informasi, pasar, teknologi, permodalan dan sumber daya lainnya. Sedangkan dampak ekonomi dilihat berdasarkan peluang aktivitas usaha dibidang pertanian khususnya padi sawah maupun padi ladang memiliki prospek yang cukup baik dan sebagai peluang bisnis yang menjadi andalan bagi peningkatan taraf hidup masyarakat petani.
\end{abstract}

Keywords : Optimasi lahan, petani

\section{Pendahuluan}

Pembangunan pedesaan diupayakan melalui peningkatan keberdayaan dan kemandirian masyarakat dalam mewujudkan kesejahteraan dalam seluruh aspek kehidupan masyarakat meliputi bidang ekonomi, sosial budaya, politik dan lingkungan. Keberdayaan dan kemandirian tercermin pada terpenuhinya sarana dan prasarana sosial dan ekonomi pedesaan, serta meningkatnya kegiatan ekonomi produktif masyarakat dan berperannya lembaga sosial ekonomi masyarakat dalam penyediaan permodalan yang ditujukan untuk mendukung peningkatan kegiatan ekonomi masyarakat dan kelembagaan sosial ekonomi masyarakat.

Luasnya lahan persawahan di Indonesia ternyata tak juga mampu membuat taraf hidup petani meningkat, masih banyak petani sawah yang mengalami kesulitan dalam menjalani hidup. Tak jarang kita dapatkan petani sawah di desa-desa berada dalam garis kemiskinan, Meningkatnya berbagai kebutuhan-kebutuhan hidup baik kebutuhan primer maupun sekunder yang biasanya dihasilkan oleh industri-industri dan juga krisis ekonomi yang tak kunjung terselesaikan, telah membuat petani miskin semakin kewalahan dalam memperbaiki perekonomian keluarga.

Melihat problematika ini, maka Pemerintah membentuk kelompok tani yang didampingi oleh penyuluh pertanian untuk membantu para petani dalam meningkatkan taraf hidup petani melalui pemberdayaan dengan pengembangan SDM salah satu program yang harus dilakukan adalah pendidikan, keterampilan dan pekerjaan.

Program Kegiatan Optimasi Lahan dilatar belakangi pemikiran bahwa lahan pertanian adalah salah satu faktor produksi yang sangat penting, karena lahan merupakan media tumbuh bagi tanaman. Banyak lahanlahan pertanian terlantar atau lahan yang sementara belum diusahakan secara optimal, tetapi apabila diberikan sentuhan teknologi maka lahan dimaksud dapat menghasilka produksi yang optimal (Direktorat Jenderal Pengelolaan Lahan dan Air, 2006).

Kegiatan optimasi lahan pertanian merupakan usaha meningkatkan pemanfaatan sumber daya lahan pertanian menjadi lahan usahatani tanaman pangan, hortikultura, perkebunan dan peternakan melalui upaya perbaikan dan peningkatan daya dukunglahan, sehingga dapat menjadi lahan usahatani yang lebih produktif. Kegiatan optimasi lahan pertanian diarahkan untuk memenuhi kriteria lahan usahatani tanaman pangan, hortikultura, perkebunan dan perternakan dari aspek teknis bentang lahan, perbaikan fisik dan kimiawi tanah, serta peningkatan infrastruktur usahatani yang diperlukan.

Kegiatan optimasi lahan diarahkan untuk menunjang terwujudnya ketahananpangan dan antisipasi kerawanan pangan, khususnya 3 (tiga) komoditi utama yaitu padi, jagung dan kedelei. Khusus di Kabupaten Simalungun (Kecamatan Pematang Silima Huta) komoditi yang dikembangkan adalah jagung.

Oleh karena itu pemerintah memberikan suatu program yang dimana bertujuan untuk meningkatkan 


\begin{tabular}{|c|c|c|c|c|c|}
\hline \multicolumn{6}{|c|}{ Program } \\
\hline & & $\mathrm{F}$ & $\%$ & $\mathrm{~F}$ & $\%$ \\
\hline 1 & $25-30$ & 5 & 25 & 5 & 25 \\
\hline 2 & $31-35$ & 4 & 20 & 4 & 20 \\
\hline 3 & $36-40$ & 3 & 15 & 3 & 15 \\
\hline 4 & $41-45$ & 4 & 20 & 4 & 20 \\
\hline 5 & $>45$ & 4 & 20 & 4 & 20 \\
\hline & nlah & 20 & 100 & 20 & 100 \\
\hline & imum & & & & \\
\hline & mum & & & & \\
\hline & -rata & & & & \\
\hline
\end{tabular}

Sumber: Data Primer

Tabel 2, menunjukkan umumnya responden petani berumur antara 25 sampai 30 tahun baik yang mengikuti program maupun tidak mengikuti program yaitu masing-masing 5 orang, demikian pula yang berumur antara $31-35$ tahun, $41-45$ tahun dan $>45$ tahun masing-masing ada 4 orang dan yang berumur antara 36 - 40 tahun ada 3 orang. Usia petani yang menjadi responden menunjukkan usia yang masih produktif, sehingga masih bisa memahami pentingnya pelaksanaan program optimasi lahan petani melalui kegiatan optimasi lahan.

\section{c. Luas Lahan}

Luas lahan dalam hal ini untuk mengetahui luas lahan yang dimiliki petani untuk berusahatani di Desa Batetangnga Kecamatan Binuang Kabupaten Polman. ditunjukkan pada Tabel 3.

Tabel 3. Identitas Responden berdasarkan Luas Lahan

\begin{tabular}{|c|c|c|c|c|c|}
\hline \multirow{2}{*}{ No } & \multirow{2}{*}{$\begin{array}{l}\text { Luas Lahan } \\
\text { (ha) }\end{array}$} & \multicolumn{2}{|c|}{ Ikut Program } & \multicolumn{2}{|c|}{ Tidak Ikut Program } \\
\hline & & $\mathrm{F}$ & $\%$ & $\mathrm{~F}$ & $\%$ \\
\hline 1 & $15-43$ & 8 & 40 & 10 & 50 \\
\hline 2 & $44-67$ & 5 & 25 & 6 & 30 \\
\hline \multirow[t]{2}{*}{3} & $68-100$ & 7 & 35 & 4 & 20 \\
\hline & Jumlah & 20 & 100 & 20 & 100 \\
\hline \multicolumn{2}{|r|}{ Maksimum } & \multicolumn{2}{|c|}{100} & \multicolumn{2}{|c|}{100} \\
\hline \multicolumn{2}{|r|}{ Minimum } & \multicolumn{2}{|c|}{15} & \multicolumn{2}{|c|}{15} \\
\hline \multicolumn{2}{|r|}{ Rata-rata } & \multicolumn{2}{|c|}{52.4} & \multicolumn{2}{|c|}{45.2} \\
\hline
\end{tabular}

Sumber: Data Primer

Tabel 3, menunjukkan luas lahan yang dimiliki petani yangikuti program ada 8 orang dengan luas lahan antara 15- 43 ha, sedangkan yang tidakmengikuti program ada 10 orang. Untuk luas lahan antara $41-67$ ha untuk petani yang ikut program ada 5 orang dan yang tidak ikut program ada 6 orang. Selanjutnya luas lahan antara $68-$ 100 ha untuk petani yang ikut program ada 7 orang dan yang tidak ikut program ada 4 orang. Keberadaan luas lahan petani ini untuk mengetahui sejauhmana pelaksanana optimasi lahan atas program optimasi lahan petani apakah memberikan keuntungan atau tidak bagi petani.

\section{d. Jumlah Produksi}

Jumlah produksi yaitu hasil yang diperoleh petani dari usaha tani ditunjukkan pada Tabel .

Tabel 4. Identitas Responden berdasarkan Jumlah Produksi

\begin{tabular}{|c|c|c|c|c|c|}
\hline \multirow{2}{*}{ No } & \multirow{2}{*}{$\begin{array}{l}\text { Jumlah } \\
\text { Produksi } \\
\text { (ton) }\end{array}$} & \multicolumn{2}{|c|}{ Ikut Program } & \multicolumn{2}{|c|}{$\begin{array}{l}\text { Tidak Ikut } \\
\text { Program }\end{array}$} \\
\hline & & $\mathrm{F}$ & $\%$ & $\mathrm{~F}$ & $\%$ \\
\hline 1 & $900-3100$ & 8 & 40 & 11 & 55 \\
\hline 2 & $3200-5300$ & 9 & 45 & 7 & 35 \\
\hline 3 & $5400-7500$ & 3 & 15 & 2 & 10 \\
\hline & Jumlah & 20 & 100 & 20 & 100 \\
\hline & Maksimum & & & & \\
\hline & Minimum & & & & \\
\hline & Rata-rata & & & & \\
\hline
\end{tabular}

Sumber: Data Primer

Tabel 4, menunjukkan hasil produksi yang diperoleh antara 900 sampai 3100 ton yang ikut program ada 8 orang dan yang tidak ikut program ada 13orang. Untuk produksi antara 3200 sampai 5300 ton ada 9 orang untuk yang ikut program dan yang tidak ikut program ada 6 orang. Produksi antara 5400 sampai 7500 ton untuk yang ikut program ada 3 orang, sedangkan yang tidak ikut program ada 1 orang. Ini berarti jumlah produksi usahatani petani ditentukan oleh luas lahan yang dimiliki, semakin luas lahan, semakin besar produksi yang dihasilkan.

\section{e. Nilai Produksi}

Nilai produksi yaitu hasil keuntungan yang diperoleh petani dari usahatani yang digelutinya berdasarkan harga per kg padi yang diterapkan. Harga per kg ditetapkan sebesar Rp. 4.000. ditunjukkan pada Tabel 5.

Tabel 5. Identitas Responden berdasarkan Nilai Produksi

\begin{tabular}{|c|c|c|c|c|c|}
\hline \multirow{2}{*}{ No } & \multirow{2}{*}{$\begin{array}{l}\text { Nilai Produksi } \\
\text { (Rp) }\end{array}$} & \multicolumn{2}{|c|}{ Ikut Program } & \multicolumn{2}{|c|}{$\begin{array}{c}\text { Tidak Ikut } \\
\text { Program }\end{array}$} \\
\hline & & F & $\%$ & $\mathrm{~F}$ & $\%$ \\
\hline 1 & $\begin{array}{l}3.600 .000- \\
12.200 .000\end{array}$ & 8 & 40 & 13 & 55 \\
\hline 2 & $\begin{array}{c}12.300 .000- \\
20.500 .000\end{array}$ & 9 & 45 & 6 & 40 \\
\hline 3 & $\begin{array}{c}20.600 .000- \\
28.000 .000\end{array}$ & 3 & 15 & 1 & 5 \\
\hline & Jumlah & 20 & 100 & 20 & 100 \\
\hline & Maksimum & 28. & & & .000 \\
\hline & Minimum & & & & 000 \\
\hline & Rata-rata & 13. & & & .000 \\
\hline
\end{tabular}

Sumber: Data Primer

Tabel 5, menunjukkan nilai produksi dari hasil usahatani petani berbeda-beda. Terlihat nilai produksi antara Rp. 3.600.000 sampai Rp. 12.200 .000 ada 8 orang untuk kelompok tani yang ikut program dan ada 13 orang untuk kelompok tani yang tidak ikut program. Untuk nilai produksi Rp. $12.300 .000-20.500 .000$ untuk petani yang ikut program ada 9 orang, sedangkan yang tidak 
ikut program ada 6 orang. Dan nilai produksi Rp.20.600.000-28.000.000 ada 3 orang untuk petani yang ikut program dan 1 orang untuk petani yang tidak ikut program.

\section{f. Pendapatan Usahatani}

Jumlah pendapatan usahatani yaitu hasil yang diperoleh dari usahatani yang sudah dipanen, ditunjukkan pada Tabel 6.

Tabel 6. Identitas Responden berdasarkan Jumlah Pendapatan Usahatani

\begin{tabular}{|c|c|c|c|c|c|}
\hline \multirow{2}{*}{ No } & \multirow{2}{*}{$\begin{array}{c}\text { Pendapatan } \\
\text { (Rp) }\end{array}$} & \multicolumn{2}{|c|}{ Ikut Program } & \multicolumn{2}{|c|}{$\begin{array}{c}\text { Tidak Ikut } \\
\text { Program }\end{array}$} \\
\hline & & $\mathrm{F}$ & $\%$ & $\mathrm{~F}$ & $\%$ \\
\hline 1 & $2.370 .000-10.600 .000$ & 11 & 20 & 17 & 35 \\
\hline 2 & $10.700 .000-17.800 .000$ & 8 & 25 & 3 & 45 \\
\hline 3 & $17.900 .000-23.475 .000$ & 1 & 15 & 0 & 20 \\
\hline & Jumlah & 20 & 100 & 20 & 100 \\
\hline & Maksimum & 23. & 000 & 17. & 0.000 \\
\hline & Minimum & 2.6 & 000 & 2.3 & .000 \\
\hline & Rata-rata & 10. & 000 & & .500 \\
\hline
\end{tabular}

Sumber: Data Primer

Tabel 6, menunjukkan nilai pendapatan dari hasil usahatani petani berbeda-beda. Terlihat nilai produksi antara Rp. 2.370.000 sampai Rp. 10.600.000ada 11 orang untuk kelompok tani yang ikut program dan ada 7 orang untuk kelompok tani yang tidak ikut program. Untuk nilai pendapatan Rp. 10.700.000 17.800.000untuk petani yang ikut program ada 8 orang, sedangkan yang tidak ikut program ada 3 orang. Dan nilai produksi Rp. $17.800 .000-24.770 .000$ ada 1orang untuk petani yang ikut program dan 0 orang untuk petani yang tidak ikut program.

\section{B. Proses Pelaksanaan Program Optimasi Lahan Petani}

Strategi dasar optimasi lahan adalah pelaksanaan Strategi dasar optimasi lahan adalah pelaksanaan identifikasi calon petani dan calon lokasi kegiatan, fasilitasi bantuan pendanaan meliputi sarana produksi pupuk maupun kapur dan olah tanah, pengawalan, pendampingan, dan penentuan paket kebutuhan optimasi lahan disesuaikan dengan kondisi lahan.

Strategi operasional pelaksanaan optimasi lahan oleh Pusat yaitu Direktorat Jenderal Prasarana dan Sarana Pertanian, Kementerian Pertanian sesuai persetujuan Direktorat Perluasan dan Pengelolaan Lahan, melaksanakan upaya Optimasi Lahan dengan tugas (1) Melaksanakan perhitungan dan penyusunan alokasi anggaran; (2) Memfasilitasi ketersediaan anggaran; dan (3) Menyusun pedoman, monitoring, evaluasi kegiatan.

Di tingkat provinsi Dinas Pertanian Propinsi berkoordinasi dengan BAKORLUH membentuk tim pembina teknis Optimasi Lahan dengan tugas sebagai berikut :
1. Melakukan verifikasi dan validasi usulan calon petani dan calon lokasi Optimasi Lahan yang diusulkan oleh Kabupaten dalam menyalurkan dana;

2. Melakukan pembinaan, monitoring, evaluasi, membuat laporan kegiatan Optimasi Lahan bersama dengan Badan Koordinasi Penyuluhan (BAKORLUH)dan Kodam dan atau Korem

Dinas pertanian kabupaten membentuk tim pelaksana teknis Optimasi Lahan dan dengan tugas sebagai berikut:

1. Mengidentifikasi dan mengusulkan calon petani dan calon lokasi (CPCL) untuk kegiatan Optimasi Lahan;

2. Melakukan verifikasi dan validasi calon petani dan calon lokasi Optimasi Lahan dan mengusulkan ke Provinsi

3. Melakukan pembinaan, monitoring, evaluasi, laporan kegiatan Optimasi Lahan bersama dengan Bapeluh dan Kodim

Ruang lingkup kegiatan pengembangan percepatan optimasi lahan berupa (1) Identifikasi calon petani dan calon lokasi (CPCL); (2) Pembuatan petunjuk pelaksanaan oleh Provinsi; (3) Pembuatan petunjuk teknis oleh Kabupaten/Kota; (4) Sosialisasi kegiatan; (5) Koordinasi; (6) Penyediaan prasarana dan sarana pertanian (7); Penanaman \& Pemeliharaan (8) Pembinaan dan pendampingan; (9) Pelaporan.

Ketentuan dan spesifikasi teknis kegiatan pengembangan optimasi lahan meliputi norma, ketentuan dan kriteria yang diterapkan petani di Desa Batetangnga untuk itu dapat dijelaskan sebagai berikut. Dilihat dari norma, optimasi lahan merupakan kegiatan perbaikan dan peningkatan kesuburan lahan yang mempunyai potensi untuk dapat meningkatkan produksi/produktifitas hasil, serta Indeks Pertanaman (IP) minimal sebesar $100 \%$ dan atau produktifitas padi meningkat 0,3 ton/ha GKP dari kondisi sebelumnya.

Ketentuan dan kriteria, pengembangan optimasi lahan dilaksanakan dengan ketentuan kriteria lokasi dan kriteria petani. Kriteria lokasi dilihat dari lahan sawah yang masih berpotensi untuk ditingkatkan IP nya minimal $100 \%$ dan atau produktivitasnya meningkat minimal 0,3 ton/ha GKP. Lokasi kegiatan tidak boleh sama dengan lokasi kegiatan Pengembangan Jaringan Irigasi (PJI) dan Gerakan Penerapan Pengelolaan Tanaman Terpadu (GP-PTT) pada tahun yang sama.Lahan sawah pada daerah kering/rawa/tadah hujan yang memiliki potensi sumber air untuk dapat mengairi lahan sawah. Selanjutnya kriteria petani dalam hal ini petani penerima manfaat tergabung dalam Kelompok Tani/P3A. Bersedia dan wajib menggunakan paket bantuan yang diberikan

Pelaksanaan kegiatan optimasi lahan dilakukan dengan pola bantuan sosial melalui transfer uang ke rekening Kelompok Tani. Adapun tahapan pelaksanaan terdiri dari (1) Persiapan; (2) Penyusunan RUKK; dan (3) Pelaksanaan Fisik.

Dalam pelaksanaan optimasi lahan, diperlukan organisasi pelaksaanaan yang bertanggung jawab dalam kelancaran pelaksanaan kegiatan antara lain koordinasi, sosialisasi, pelaksanaan, pembinaan, pendampingan, pengawalan, monitoring dan pelaporan mengacu pada 
pedoman UPSUS peningkatan produksi padi, jagung dan kedelai melalui program perbaikan jaringan irigasi dan sarana pendukungnya tahun anggaran 2015.

Kegiatan optimasi lahan dan pendukungnya memerlukan proses pemberdayaan dalam bentuk pengawalan dan pendampingan oleh Perguruan Tinggi dan Penyuluh Pertanian dengan memperhatikan aspek teknis, sosial, budaya, ekonomi, dan lingkungan.

\section{Tingkat Desa}

a.Pengawalan dan pendampingan Optimasi Lahan di tingkat desa menjadi tugas penyuluh pertanian yang bersangkutan;

b.Pendampingan yang bersifat teknis dilakukan berkoordinasi dengan petugas lapangan/perangkat UPT Dinas yang menangani pertanian di kecamatan;

c. Secara khusus tugas pengawalan dan pendampingan yang dilakukan yaitu:

1) Mengecek ulang persyaratan kelompok penerima manfaat dan lokasi

2) Melakukan pengawalan dan pendampingan pemberkasan administrasi bantuan di tingkat kelompok (RUKK). Penyusunan RUKK dilaksanakan dengan musyawarah Poktan/P3A dengan bimbingan Tim Teknis atau koordinator lapangan. RUKK yang telah disusun harus disetujui oleh Tim teknis/koordinator lapangan dan diketahui oleh KPA/PPK;

3) Melakukan pengawalan pelaksanaan kegiatan optimasi lahan

4) Menyusun dan menyampaikan laporan kepada Pimpinan BP3K.

\section{Tingkat Kecamatan}

a. Balai Penyuluhan, Perikanan dan Kehutanan (BP3K) dan Koramil melakukan koordinasi pengawalan dan pendampingan kegiatan optimasi lahan yang dilaksanakan oleh penyuluh dan Babinsa di masing-masing desa;

b. Kepala BP3K/koordinator penyuluh dalam merencanakan kegiatan penyuluhan berkoordinasi dengan petugas lapangan / perangkat UPTD di kecamatan, yang menangani pertanian tanaman pangan dan pengairan;

c. Melakukan koordinasi pelaksanaan pengawalan dan pendampingan yang dilakukan oleh para penyuluh melalui metode Latihan dan Kunjungan (LAKU) yang terjadwal;

d. Koordinasi pengawalan dan pendampingan di tingkat kecamatan meliputi:

1) Melakukan supervisi dan monitoring pelaksanaan Kegiatan optimasi lahan di tingkat Desa;

2) Melakukan rekapitulasi laporan masing-masing penyuluh dan Babinsa terhadap kegiatan optimasi lahan di wilayah kerjanya;

3) Menyerahkan rekapitulasi laporan kepada KCD dengan tembusan kepada Kepala Badan Pelaksana Penyuluhan (Bappeluh)/kelembagaan yang menangani penyuluhan di tingkat kabupaten/kota;

4) Apabila tidak ada $\mathrm{KCD}$, maka rekapitulasi laporan diserahkan langsung kepada Kepala Dinas Pertanian Kabupaten/Kota dengan tembusan kepada Kepala Bappeluh/kelembagaan yang menangani penyuluhan di tingkat kabupaten/kota.

\section{Tingkat Kabupaten/kota}

a. Koordinasi pengawalan dan pendampingan kegiatan optimasi lahan dilakukan oleh Kepala Dinas Pertanian, Kepala Bappeluh atau kelembagaan yang menangani penyuluhan pertanian kabupaten/kota dan Komandan Komando Distrik Militer.

b. Sinkronisasi kegiatan pengawalan dan pendampingan dilaksanakan secara terintegrasi, meliputi:

1) Melakukan supervisi dan monitoring pelaksanaan kegiatan pengawalan dan pendampingan oleh penyuluh Dinas Pertanian dan Staf Kodim dalam kegiatan optimasi lahan di tingkat Kecamatan;

2) Melakukan rekapitulasi laporan masing-masing BP3K terhadap kegiatan optimasi lahan

3) Menyerahkan rekapitulasi laporan kepada Dinas Pertanian dan Sekretariat Badan Koordinasi Penyuluhan (BAKORLUH).

\section{Tingkat Provinsi}

a. Koordinasi pengawalan dan pendampingan kegiatan optimasi lahan dilakukan oleh Kadistan Pangan Propinsi Kepala Sekretariat BAKORLUH atau kelembagaan yang menangani penyuluhan pertanian provinsi dan Asisten Teritorial Komando Daerah Militer (Aster Kodam)/Kasiter Komando Resort Militer (Korem).

b. Sinkronisasi kegiatan pengawalan dan pendampingan dilaksanakan secara terintegrasi;

c. Melakukan supervisi dan monitoring pelaksanaan kegiatan optimasi lahan di tingkat Kabupaten/Kota;

d. Melakukan rekapitulasi laporan masing - masing Kabupaten/Kota terhadap kegiatan optimasi lahan

e. Menyerahkan rekapitulasi laporan kepada Kepala Badan Penyuluhan dan Pengembangan SDM Pertanian cq. Pusat Penyuluhan Pertanian.

\section{Tingkat Pusat}

Koordinasi kegiatan Optimasi Lahan dilakukan Ditjen PSP selaku Ketua I :

a. Menyelenggarakan rapat koordinasi perencanaan pengawalan dan pendampingan yang dihadiri oleh tim Penanggungjawab Propinsi;

b. Mengendalikan pelaksanaan pengawalan dan pendampingan melalui penanggung jawab Propinsi;

c. Melakukan pemantauan terhadap pelaksanaan kegiatan pengawalan dan pendampingan penyuluhan pertanian di tingkat nasional;

d. Melakukan evaluasi dan menyusun pelaporan pengawalan dan peddampingan di tingkat nasional.

Dalam sistem pengawasan pada sistem penganggaran terpadu berbasis kinerja, perlu dilakukan penilaian terhadap capaian kinerja outputs dan outcomes dari kegiatan optimasi lahan, untuk memberikan keyakinan bahwa sasaran dan tujuan dari kegiatan dapat tercapai sesuai dengan prinsip efisien, ekonomis, efektif, dan sesuai dengan ketentuan yang berlaku.

Sehubungan dengan hal tersebut dan sesuai dengan Peraturan Pemerintah RI No. 60 tahun 2008 tentang Sistem Pengendalian Intern Pemerintah (SPIP), dalam pelaksanaan kegiatan Optimasi Lahan perlu dilakukan Pengawasan Intern oleh Aparat Pengawas Internal 
Pemerintah (APIP) Kementerian Pertanian yaitu Inspektorat Jenderal Kementerian Pertanian.

Pengawasan Intern meliputi seluruh proses kegiatan audit, reviu, evaluasi, pemantauan, dan kegiatan pengawasan lain terhadap penyelenggaraan tugas dan fungsi organisasi dalam rangka memberikan keyakinan yang memadai bahwa kegiatan Optimasi Lahan telah dilaksanakan sesuai dengan tolok ukur yang ditetapkan secara efektif dan efisien untuk kepentingan pimpinan dalam mewujudkan tata kepemerintahan yang baik.

Pengendalian terhadap pelaksanaan kegiatan optimasi lahan dilaksanakan mulai dari tahapan persiapan, penyiapan dokumen, pelaksanaan dan pasca pelaksanaan yang dilaksanakan secara berjenjang mulai dari Pusat, Propinsi dan Kabupaten/Kota.

Untuk mengendalikan pelaksanaan Optimasi Lahan tingkat pusat dilakukan melalui pembinaan reguler dan kunjungan ke Propinsi, Kabupaten/Kota dan lapangan untuk menjamin pelaksanaan Optimasi Lahan $\backslash$ sesuai dengan kebijakan umum yang tertuang dalam Pedoman Teknis Optimasi Lahan dari Ditjen PSP.

Pengendalian pelaksanaan Optimasi Lahan di tingkat Propinsi, Kepala Dinas Pertanian Propinsi melakukan pengendalian kegiatan melalui pembinaan reguler dan kunjungan lapangan ke Kabupaten/Kota dan kecamatan untuk menjamin pelaksanaan Optimasi Lahan sesuai dengan kebijakan teknis Optimasi Lahan serta menyelesaikan permasalahan yang terjadi di lapangan sesuai dengan Pedoman Teknis yang dikeluarkan oleh Direktorat Perluasan dan Pengelolaan lahan Ditjen PSP.

Tim Teknis Kabupaten/Kota melakukan pengendalian terhadap pelaksanaan Optimasi Lahan melalui pembinaan reguler dan kunjungan lapangan ke Kecamatan dan Desa untuk menjamin pelaksanaan kegiatan Optimasi Lahan sesuai dengan pedoman pelaksanaan yang dikeluarkan oleh Dinas Pertanian Propinsi menyelesaikan permasalahan yang terjadi di lapangan.

Tujuan pengendalian untuk meningkatkan Indeks Pertanaman (IP) dan produktifitas lahan sawah melalui penyediaan sarana produksi (pupuk) dan bantuan pengolahan tanah.

Dalam pelaksanaan optimasi lahan terdapat pengertianpengertian/istilah, sebagai berikut :

1. Optimasi lahan adalah usaha meningkatkan Indeks Pertanaman (IP) dan produktifitas melalui penyediaan sarana produksi pupuk/kapur dan pengolahan tanah.

2. Sawah adalah lahan usahatani yang secara fisik permukaan tanahnya rata, dibatasi oleh pematang, sehingga dapat ditanami padi dengan sistem genangan atau pengairan berselang.

3 Indeks Pertanaman (IP) adalah frekuensi penanaman pada sebidang lahan pertanian untuk memproduksi bahan pangan dalam kurun waktul tahun.

4.Produktifitas hasil adalah satuan hasil produksi sebagai output dalam satu hektar sawah yang dioptimasi persatuan input

\section{Dampak Sosial Ekonomi dari Pelaksanaan Program Optimasi Lahan Petani}

\section{a. Produksi}

Berdasarkan hasil penelitian yang dilakukan di Desa Batentangga Kecamatan Binuang diketahui jumlah produksi yang dihasilkan oleh petani yang ikut program optimasi lahan rata-rata jumlah produksi yang diperoleh sebesar 3.5 ton dengan jumlah maksimum produksi yang dicapai sebesar 7.5 ton dan minimun 1.1 ton, sedangkan produksi yang diperoleh dari petani yang tidak mengikuti program sebanyak 2.7 tondengan jumlah maksimum produksi yang dicapai sebesar 6 ton dan minimun 0.9 ton, untuk masing-masing 20 responden petani yang diamati. Ini dapat diinterpretasikan bahwa petani yang mengikuti program pencapaian produksi lebih tinggi dibandingkan dengan pencapaian produksi petani yang tidak mengikuti program.

Selain itu, diketahui bahwa nilai produksi yang diperoleh petani berkaitan dengan kemampuan mengelola lahan usahataninya antara petani yang mengikuti program dan yang tidak mengikuti program, nilai produksi yang dicapai untuk petani yang ikut ratarata Rp. 13.940.000 dengan nilai maksimum $\mathrm{Rp}$. 28.000.000 dan minimun Rp. 4.000.000. Sementara nilai produksi dari petani yang tidak ikut program mencapai rata-rata Rp. 10.320 .000 dengan maksimum $\mathrm{Rp}$. 24.000.000 dan minimun Rp. 3.600.000. Ini dapat diartikan bahwa nilai produksi yang diperoleh petani yang mengikuti program lebih menguntungkan dibandingkan dengan petani' yang tidak mengikuti program, dengan selisih Rp. 3.560.000.

\section{b.Pendapatan}

Berdasarkan hasil penelitian yang dilakukan di Desa Batentangga Kecamatan Binuang diketahui jumlah pendapatan yang dihasilkan oleh petani yang ikut program optimasi lahan rata-rata jumlah pendapatanyang diperoleh sebesar Rp 10.143.000 dengan jumlah pendapan maksimum Rp 23.475.000 yang dicapai dan minimun Rp 2.616.000, sedangkan pendapatan rata-rata yang diperoleh dari petani yang tidak mengikuti program Rp 7.081.500 dengan jumlah maksimum pendapatan yang dicapai sebesar Rp 17,000.000 dan minimun Rp2.245.000, untuk masing-masing 20 responden petani yang diamati. Ini dapa dibandingkan bahwa petani yang mengikuti program pencapaian pendapatan lebih tinggi dibandingkan dengan pencapaian pendapatan petani yang tidak mengikuti program.

Pendapatan usahatani yaitu suatu analisis dalam menentukan besarnya tingkat pendapatan yang diperoleh dari hasil pengelolaan usahatani dalam memberikan keuntungan dari besarnya pendapatan yang diperoleh dari total revenue yaitu total produksi yang sesuai dengan harga dikurangi dengan total biaya yang sesuai dengan besarnya biaya produksi yang dikeluarkan. Berikut ini disajikan pada Tabel 7

Tabel 7 Analisis Perhitungan R/C Ratio

\begin{tabular}{ccc}
\hline \multirow{2}{*}{ Uraian } & Kelompok Tani & Kelompok Tani \\
& Program & Bukan \\
& Optimasi & Program \\
& Lahan & Optimasi Lahan \\
\hline
\end{tabular}

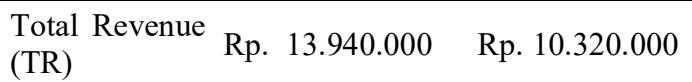




$$
\begin{aligned}
& \begin{array}{llll}
\text { Total Cost } & \text { Rp. } 3.797 .000 & \text { Rp. } 3.238 .500 \\
\text { (TC) } & &
\end{array} \\
& \pi(\mathrm{TR}-\mathrm{TC}) \quad \text { Rp. } 10.143 .000 \quad \text { Rp. } 7.081 .500 \\
& \text { R/C Ratio (TR } 3.67 \quad 3.18
\end{aligned}
$$$$
\text { Sumber: Data primer }
$$

Berdasarkan perhitungan di atas menunjukkan nilai $\mathrm{R} / \mathrm{C}$ rasio yang dihasilkan petani kelompok tani baik yang tidak mengikuti program optimasi lahan maupun yang mengikuti program optimasi lahan di Desa Batetangnga Kecamatan Binuang Kabupaten Polman menghasilkan nilai $\mathrm{R} / \mathrm{C}$ rasio $>1$. Kelompok tani yang ikut program diperoleh $\mathrm{R} / \mathrm{C}$ ratio sebesar 3.67 dan yang tidak mengikuti program diperoleh $\mathrm{R} / \mathrm{C}$ ratio sebesar 3.18. Nilai R/C ratio untuk kelompok tani yang mengikuti program optimasi lahan lebih tinggi dibandingkan yang tidak mengikuti program optimasi lahan. Ini berarti evaluasi atas program optimasi lahan petani di Desa Batetangnga, Kecamatan Binuang Kabupaten Polewali Mandar sudah sesuai SOP dan memberikan hasil yang menguntungkan bagi anggota kelompok tani yang mengikutinya karena tingkat penerimaan yang diperoleh petani lebih tinggi dibandingkan dengan penerimaan anggota kelompok tani yang tidak ikut program.

\section{Evaluasi Program optimasi lahan petani melalui Kegiatan Optimasi Lahan}

Evaluasi pelaksanaan kegiatan optimasi lahan yang dilaksanakan oleh tim monitoring dan evaluasi yang ditunjuk oleh direktur perluasan dan pengelolaan lahan, Direktorat Jenderal Prasarana dan Sarana Pertanian. Tim monitoring dan evaluasi melakukan evaluasi terhadap pelaksanaan optimasi lahan mencakup evaluasi awal, evaluasi pelaksanaan yang sedang berjalan dan evaluasi akhir. Evaluasi pelaksanaan optimasi lahan di Desa Batetangnga dilakukan oleh tim pembina teknis kabupaten/kota. Kabupaten/Kota untuk melakukan evaluasi awal, evaluasi pelaksanaan yang sedang berjalan dan evaluasi akhir.

Laporan pengendalian dilakukan secara berjenjang. Untuk pelaporan pengendalian supaya melampirkan juga laporan dari kabupaten. Laporan perkembangan per bulan pelaksanaan kegiatan optimasi lahan dapat disampaikan melalui Aplikasi Model Pelaporan Online (MPO). Dinas lingkup pertanian kabupaten/kota melakukan rekapitulasi laporan dari kelompok dan mengirimkan ke Dinas Pertanian Provinsi dengan tembusan ke Pusat (Direktorat Perluasan dan Pengelolalaan Lahan). Dinas lingkup pertanian provinsi melakukan rekapitulasi laporan dari dinas lingkup pertanian kabupaten/kota dan mengirimkan ke Pusat (Direktorat Perluasan dan Pengelolalaan Lahan). Untuk laporan Triwulan dikirim sesuai jadual yang telah ditentukan.

Untuk mengetahui keberhasilan pelaksanaan kegiatan optimasi lahan maka ditentukan indikator kinerja sebagai berikut :
1. Indikator Keluaran (Outputs). Terealisasi kegiatan pengembangan Optimasi Lahan seluas $10 \mathrm{Ha}$

2. Indikator Hasil (Outcomes)

a. Meningkatnya indeks pertanaman (IP) minimum sebesar $100 \%$ dari kondisi sebelumnya; dan

b. Meningkatnya produksi dan produktifitas hasil padi minimum 0,3 ton/ha gabah kering.

Untuk mengevaluasi hasil optimasi lahan dapat dilihat dari hasil produksi antara yang mendapat program dan yang tidak mendapat program. Indikator manfaat (benefits) yaitu meningkatnya produksi padi pada lahan sawah lokasi kegiatan optimasi lahan. Indikator dampak (impacts) dilihat dari terwujudnya peningkatan pendapatan masyarakat petani, terwujudnya peningkatan kesejahteraan masyarakat petani akibat meningkatnya produksi padi, dan terwujudnya Ketahanan Pangan Daerah dan Nasional.

Kegiatan optimasi lahan yang dilaksanakan pada lahan sawah diharapkan dapat meningkatkan Indeks Pertanaman serta meningkatnya produksi dan produktifitas hasil. Optimasi lahan difokuskan pada pemberian sarana produksi pupuk/kapur serta bantuan olah tanah. Strategi pelaksanaan kegiatan optimasi lahan dilakukan secara terpadu dan kerjasama partisipatif dengan petani, sehingga dapat memberikan dampak positif terhadap peningkatan produksi padi dan penyerapan tenaga kerja.

Adapun kriteria untuk mengikuti program optimasi lahan dan Tahap pelaksanaan kegiatan pemberdayaan petani melalui program optimasi lahan yang dambil dari respon petani di sajikan pada tabel 8 .

\begin{tabular}{|c|c|c|c|c|c|}
\hline \multirow[t]{2}{*}{ No } & \multirow[t]{2}{*}{ Kriteria Penilaian } & \multicolumn{4}{|c|}{ Respon Petani } \\
\hline & & ya & $\%$ & Tidak & $\%$ \\
\hline 1 & $\begin{array}{l}\text { Luas lahan petani } \\
\text { dalam kelompok } \\
\text { tani minimal } 10 \\
\text { ha. }\end{array}$ & 20 & 100 & 0 & 0 \\
\hline 2 & $\begin{array}{l}\text { Jenis lahan } \\
\text { beririgasi teknis }\end{array}$ & 20 & 100 & 0 & 0 \\
\hline 3 & $\begin{array}{l}\text { Menjadi Anggota } \\
\text { KelompokTani }\end{array}$ & 20 & 100 & 0 & 0 \\
\hline 4 & $\begin{array}{l}\text { Menerima } \\
\text { bantuan usahatani } \\
\text { sebesar Rp } \\
2.100 .000 / \mathrm{Ha}\end{array}$ & 20 & 100 & 0 & 0 \\
\hline
\end{tabular}

Tabel 8. Kriteria Penilaian Respondan yang Mengikuti Program dan yang Tidak mengikuti Program Optimasi

Sumber: Data primer

Tabel 8 menunjukkan bahwa tanggapan respoden untuk kriteria optimasi lahan lebih banyak yang mengikuti kriteria tersebut dapat dilihat bahwa untuk kriteria: 1) Luas lahan petani dalam kelompok tani minimal $10 \mathrm{Ha}$ untuk respon petani menunjukkan bahwa yang mengIkuti ada 20 orang, 2) Jenis lahan beririgasi untuk respon petani menunjukkan 20 orang respoden telah memenuhi kriteria, 3) Menjadi anggota kelompok tani menunjukkan bahwa untuk respon petani ada 20 orang responden telah memenuhi kriteria, 4) Menerima 
bantuan usahatani sebesar Rp 2.100.000 menunjukkan bahwa ada 1 kelompok yang mendapatkan bantuan berjumlah 20 orang, sehingga dari hasil tanggapan responden tersebut di atas dapat disimpulkan bahwa kriteria responden yang disalurkan bantuan oleh pemerintah kepada petani padi sudah sesuai dengan kriteria yang telah di tetapkan dan dapat menerima bantuan.

Adapun tujuan pelaksanaan program optimasi diharapkan dapat meningkatkan indeks pertanaman serta meningkatkan produksi dan produktivitas hasil usahaatani. Optimasi lahan difokuskan pada pemberian sarana produksi adapun tanggapan responden tentang indeks pencapain program optimasi lahan yang akan di sajikan pada tabel 9 .

Tabel 9. Tanggapan Responden Tentang Indeks Pencapain Program Optimasi Lahan

\begin{tabular}{clcccc}
\hline & & \multicolumn{4}{c}{ Respon Petani } \\
No & Kriteria Penilaian & ya & $\%$ & tidak & $\%$ \\
\hline 1 & $\begin{array}{l}\text { Indek } \\
\text { pertanaman (IP) } \\
\text { meningkat } \\
\text { minimal 0,5 \% } \\
\text { Peningkatan }\end{array}$ & 0 & 0 & 20 & 100 \\
2 & $\begin{array}{l}\text { Produksi dan } \\
\text { Produktivitas } \\
\text { padi minimum } \\
\text { 0.3 Ton / Ha }\end{array}$ & 20 & 100 & 0 & 0 \\
\hline Sumber: Data primer & & & & \\
\hline
\end{tabular}

Hasil Tabel 9 menunjukkan bahwa hasil tanggapan responden mengenai hasil produksi usahatani yang menunjukkan kriteria penilaian indeks peningkatan pertanaman tidak meningkat $100 \%$ karena dipengaruhi oleh faktor iklim, menunjukkan bahwa tanggapan responden terhadap indeks pertanaman tersebut tidak mencapai sasaran yang diharapkan. Sedangkan untuk peningkatan hasil produksi usahatani yang dikelola oleh petani peningkatan produktivitas memperoleh hasil 0.3 ton/ha untuk masing-masing responden petani padi Berikut ditunjukkan rekapitulasi dampak sosial ekonomi pada tabel 10 .

Tabel 10 Rekapitulasi Dampak Sosial dan Ekonomi

\begin{tabular}{|c|c|c|}
\hline No & Kegiatan & Dampak \\
\hline 1 & $\begin{array}{l}\text { Aspek Sosial } \\
\text { Kerjasama petani } \\
\text { dalam kelompok }\end{array}$ & $\begin{array}{l}\text { Dampak sosial dalam hal ini dilihat } \\
\text { dari kerjasama petani dalam } \\
\text { kelompok taninya dari pelaksanaan } \\
\text { program optimasi lahan dapat di } \\
\text { katakan terjadi peningkatan karena } \\
\text { para petani melakukan kegiatan } \\
\text { secara swadaya yakni membirsikan } \\
\text { irigasi sawa, pembuatan pupuk } \\
\text { organik ( puppuk kandan) dan pada } \\
\text { saat penanaman padi }\end{array}$ \\
\hline 2 & $\begin{array}{l}\text { Aspek Ekonomi } \\
\text { Produksi }\end{array}$ & $\begin{array}{l}\text { Produksi rata-rata kelompok tani } \\
\text { peserta program optimasi lahan } \\
\text { lebih tinggi bila dibandingkan } \\
\text { kelompok tidak mengikuti program }\end{array}$ \\
\hline
\end{tabular}

Pendapatan Begitu juga pendapatan rata-rata kelompok tani peserta program lebih tinggi bila dibandingkan kelompok tidak mengikuti program
Sumber: Data primer

\section{Kesimpulan}

Berdasarkan hasil penelitian, maka kesimpulan penelitian ini adalah sebagai berikut:

1. Pelaksanaan program optimasi lahan petani melalui Program Optimasi Lahan sudah sesuai dengan kriteria optimasi lahan menurut ketentuan Dinas Pertanian Kabupaten Polman yaitu luas lahan 10 ha, telah memasukkan proposal yang sesuai dengan SK Bupati, petani tergabung dalam kelompok tani yang terdaftar; dan menerima bantuan Rp. 2.100.000/ha.

2. Dampak sosial pelaksanaan program optimasi lahan adalah kerjasama antara anggota kelompok dalam kelompok tani dan diarahkan untuk memberikan pengetahuan kelembagaan usahatani. Sedangkan dampak ekonomi adalah produksi dan pendapatan meningkat antara kelompok tani yang mengikuti program optimasi lahan lebih tinggi dibanding yang tidak mengikuti program.

3. Evaluasi optimasi lahan menunjukkan bahwa indeks pertanaman yang dilakukan oleh petani padi tidak mengalami peningkatan $100 \%$ dikarenakan faktor iklim yang menyebabkan tidak mencapai sasaran yang diharapkan. Sementara produktivitas usahatani padi yang dikembangkan oleh petani yang mengikuti program mengalami peningkatan sebesar 0.3 ton/ha.

\section{Daftar Pustaka}

Andriani, Y. 2013, Pengembangan Bahan Ajar Kenampakan Bumi Berbasis Keterampilan Proses Melalui Pendekatan PCK di Sekolah Dasar. Skripsi, Pendidikan Guru Sekolah Dasar, Universitas Pendidikan Indonesia.

Abdurahman M dan Muhidin S A. 2007. Analisis Korelasi, Regresi, dan Jalurdalam Penelitian. Penerbit :Pustaka Setia, Bandung

Adiwilaga, Anwas., 2002, Pengantar Ilmu Pertanian, Penerbit : Rineka Cipta, Jakarta

Arikunto, Suharsimi. 2010. Prosedur Penelitian Suatu Pendekatan Praktik. Penerbit ; Rineka Cipta, Jakarta

Dyah Puspita Ratna, 2012. Pemberdayaan Petani Melalui Gabungan Kelompok Tani (Gapoktan) di Desa Jendi Kecamatan Selogiri Kabupaten Wonogiri Jawa Tengah.

Galih Pratama Nuranto, 2013.Pemberdayaan Masyarakat Petani Padi Organik (studi Pemberdayaan Paguyuban Petani Al-barokah Desa Ketapang Kecamatan Sususkan Kabupaten Semarang).

Gaspersz, V. 2000. Manajemen Produktivitas Total. Penerbit :Gramedia Pustaka Utama, Jakarta

Ghozali, Imam. 2013. Aplikasi Analisis Multivariate Dengan Program. Edisi Ketujuh. Semarang: Badan Penerbit Universitas Diponegoro

Herjanto, Eddy. 2007. Manajemen Produksi dan Operasi. edisi Ketiga. Penerbit :Grasindo, Jakarta 
Hermanto dan Swastika Dewa KS.2011.Farmers'Groups Empowerment as an Initial Step to Farmers'Welfare Improvement.Jurnal Analisis Kebijakan Pertanian.[Internet].[Diunduh pada tanggal 13 Februari 2014];9(4):Pusat Sosial Ekonomi dan Kebijakan Pertanian Bogor.Tersedia pada: Error! Hyperlink reference not valid.

Jack Mangowal, 2011. Pemberdayaan Masyarakat Petani Dalam Meningkatkan Pengembangan Ekonomi Pedesaan di Desa Tumani Kecamatan Maesaan Kabupaten Minahasa Selatan.

Karyadi,2009.PemberdayaanMasyarakat Petani Melalui Penyuluhan Untuk Peningkatan Produktivitas Lahan Kritis di Desa Mekrjaya Kecamatan Arjasari Kabupaten Bandung.

Kriyantono, Rahmat. 2009. Teknik Praktis Riset dan Komunikasi, Penerbit Kencana, Jakarta:

Mardikanto, Totok, Poerwoko Soebiato. 2012. Pemberdayaan Masyarakat Dalam Perspektif Kebijakan Publik, Penerbit : Alfabeta. Bandung.

Moleong, Lexy J. 2011. Metodologi Penelitian Kualitatif (Edisi Revisi). Penerbit :Remaja Rosdakarya Offset, Bandung

Nasdian FT. 2014. Pengembangan Masyarakat. Bogor (ID): Yayasan Pustaka Obor Indonesia

Nasrul, Wedy. 2012. "Pengembangan Kelembagaan Pertanian Untuk PeningkatanKapasitas Petani Terhadap Pembangunan Pertanian”. Jurnal Menara Ilmu.Vol. III No.29, Juni 2012.

Najmudinrohman .2010. Pengaruh Kemitraan Terhadap Usaha Tani Tebu di Kecamatan Trangkil Pati Jawa Tengah. Skripsi. Fakultas Pertanian Institute Pertanian Bogor.

Peraturan

Menteri

Pertanian

Nomor/Permentan/OT.140/8/2013

TentangPedoman Pembinaan Kelompoktani dan Gabungan Kelompoktani

Rodjak, 2006.Manajeman Usaha Tani.Pustaka Gitaguna Bandung

Soetomo. 2013. Pemberdayaan Masyarakat. Penerbit :Pustaka Pelajar. Yogyakarta

Suharto, Edi, 2005, Membangun Masyarakat Memberdayakan Rakyat, cetakan pertama, Penerbit : Refika Aditama.Jakarta

Saskia, D. Y. 2012. Biaya dan Pendapatan Usahatani Tebu Menurut Status Kontrak (Studi Kasus di PT IGN Cepiring, Kab. Kendal). diponegoro Journal of Economics, 1-12

Suparjan, dan Hempri Suyatno. 2003. Pengembangan Masyarakat: DariPembangunan Sampai Pemberdayaan. Penerbit :Aditya Media, Yogyakarta

Syamsuddin; Neldysavrino; Komarudin, Heru; \& Siagian, Y.L. 2007. Sudahkah Aspirasi Masyarakat Terakomodir dalam Rencana Pembangunan. Paper Governance Brief, Nomor 34(b). Bogor:Center for International Forestry Research.

Suharto, Edi. 2005. Analisis Kebijakan Publik: Panduan Praktis MengkajiMasalah dan Kebijakan Sosial. Penerbit :Alfabeta, Bandung.
Soedjatmoko. 2003. Dimensi Manusia dalam Pembangunan. Penerbit :PustakaLP3ES Indonesia, Jakarta

Slamet, Margono. 2001. Perspektif Ilmu Penyuluhan Pembangunan Menyongsong Era Tinggal Landas dalam Penyuluhan Pembangunan di Indonesia : Menyongsong Abad 21. Penerbit : Pustaka Pembangunan Swadaya Nusantara. Jakarta

Sadikin M., 2001, Pengembangan Sektor Pertanian (Penanganan Komoditi Unggul), UGM Press, Jakarta.

Undang Undang Nomor 19 Tahun 2013 tentang Perlindungan dan Pemberdayaan Petani, Lembaran Negara Republik Indonesia Tahun 2013 Nomor 131, Tambahan Lembaran Negara Republik Indonesia Nomor 5433.

Usman, Sunyoto. 2004. Pembangunan dan Pemberdayaan MasyarakatYogyakarta: Penerbit Pustaka Pelajar

Widjajanti K. 2011 Juni. Model pembedayaan masyarakat. Dalam: Jurnal Ekonomi Pembangunan. [Internet]. [Dikutip 12 Mei 2015]; 12 (!): 15-27. Dapat diunduh dari:Error! Hyperlink reference not valid..

Wolf, Erick. R, 2004.Petani Suatu Tinjauan Antropologis, Penerbit : Rajawali Pers, Jakarta

Yustika, Erani. Ahmad. 2003. Negara VS Kaum Miskin. Penerbit :Pustaka Pelajar, Yogyakarta

Zubaedi. 2013. Pengembangan Masyarakat.Penerbit :Kencana. Jakarta.

http://www.sejarah-negara.com/2014/09/4-upayapeningkatan-Produkvitashtml Konten adalah milik dan hak ciptawww.sejarah-negara.com 